\title{
Yapıcı Özür Dilemenin Müşteri Affediciliğindeki Rolü: Kırıkkale İlinde Market Alışverişlerine Yönelik Bir Araştırma
}

\author{
DOI: $10.26466 /$ opus.568542
}

\author{
* \\ Ertuğrul Karakaya* İbrahim Bozac1** \\ * Dr. Öğr. Üye. Kırıkkale Üni., Fatma Şenses Sosyal Bilimler MYO, Bahşılı / Kırıkkale / Türkiye \\ E-Posta: erkara@hotmail.com \\ ORCID: 0000-0001-5049-4588 \\ ** Dr. Öğr. Üye. Kırıkkale Üni., Keskin MYO, Keskin/Kırıkkale/ Türkiye \\ E-Posta: iborganizer@gmail.com \\ ORCID: $\underline{0000-0002-9584-6126}$
}

Öz

Ticari ilişkilerde, müşterilerin mal, hizmet, süreç veya çalışan davranışlarn gibi nedenlerle işletme hataları ile karşılaşması kaçınılmazdır. İşletme hataları sonucunda müşteri tutum ve davranışlarının olumsuz hale gelmesinin mümkün olduğ u bilinmektedir. Bu durumun işletmelerin istedikleri sonuçlara ulaşmasını olumsuz etkilemesi söz konusudur. İşletmelerin yaptı̆̆ı hataların olumsuz sonuçlarını ortadan kaldırmada, müşterinin işletme hatalarını affetmesini sağlamak önemli bir yöntemdir. Bu çalışmada, yapıcı özür dilemenin müşteri affediciliŭindeki rolü incelenmektedir. Bu kapsamda, öncelikle müşteri affediciliği ve özür dilemenin müşteri affediciliğindeki rolü, hizmet sektöründe yoğun olarak gerçekleştirilen ikincil veriler yardımıla açıklanmaktadır. Ardından, müşterilerin market alışverişlerinde karşılaştığı işletme hatalarında özür dileme ve müşteri affediciliği ilişkisini incelemek için Kırıkkale ilinde kolayda örnekleme yöntemiyle gerçekleştirilen anket çalışmasıyla birincil veriler toplanmaktadır. Analiz sonuçlarına göre, yapıcı özür dilemenin müşterinin işletmeyi affetmesini sağlamada önemli rol üstlendiği tespit edilmektedir. Hata türlerine göre, yapıcı özür dilemenin affedicilikle ilişkileri karşılaştırıldığında, fiyat ve ödeme koşullarıyla ilgili hatalarda özür dilemenin daha etkili olduğu görülmektedir. Son olarak, araştırma bulguları yorumlanmakta ve hem akademisyenlere hemde işletmelere yardımcı bir çalışma olması hedeflenmektedir.

Anahtar Kelimeler: İşletme Hataları, Özür dileme, Affedicilik, Müşteri affediciliği 


\title{
The Role of Constructive Apology in Customer Forgiveness: A Research on Market Shopping in Kirıkkale Province
}

\begin{abstract}
In commercial relations, it is inevitable for customers to encounter business errors due to goods, services, processes or employee behaviors. It is known that it is possible that customer attitudes and behaviors become negative as a resutl of business faults. This situation has a negative effect on the achievement of the desired results of the businesses. In order to eliminate the negative consequences of the faults made by firms, it is an important method to ensure that customer forgive the mistakes of the businesses. In this study, the role of constructive apology in customer forgiveness is examined. In this context, firstly, customer forgiveness and the role of apology in customer forgiveness is explained with the help of secondary data that produced intensively in the service sector. Then, primary data is collected by survey method which is carried out in Kırlkkale province with convenience sampling methot in order to examine the relationship between apology and customer forgiveness in the case of business faults that customers face in grocery shopping. According to the results of the analysis, it is determined that constructive apology plays an important role in ensuring the customer forgiveness. When the relationship between constructive apology and forgiveness is compared according to firm fault types, it is seen that apology is more effective in terms of problems about price and payment conditions. Finally, the findings of the research are interpreted and it is aimed to help both academicians and businesses.
\end{abstract}

Keywords: Business Faults, Apology, Forgiveness, Customer Forgiveness 


\section{Giriş}

Daha çok felsefe ve teoloji kapsamında incelenen "affedecilik" konusu, son zamanlarda, sosyal bilimler araştırmacılarının da ilgisini çekmektedir. Pazarlama araştırmacıları affediciliğin, tüketici davranışlarında önemli etkilerinin olabileceğini ileri sürmektedir (Xie ve Peng, 2009; Beverland vd., 2009; Beverlan vd., 2010; Tsarenko ve Tojib, 2012). Ancak müşteri affediciliği, işletmelerde yeterince incelenmiş bir konu değildir (Tsarenko ve Tojib, 2011). Diğer taraftan hizmet hataları karşısında müşterilerin tepkileri; pazarlama literatüründe daha çok müşterinin misilleme, şikâyet etme ve firma değiştirme davranışları bakımından incelenmiştir (Grégoire vd., 2009). Müşteri ile ilişkilerin zarar görmemesi ve düzeltilmesi için, işletme veya çalışanlarının yaptığı hataların müşteri tarafından affedilmesine yönelik nelerin yapılması gerektiği incelenmesi gereken bir konudur. Müşteri affediciliğini etkileyen değişkenlerin anlaşılması, müşterilerin kaybedilmemesine ve doğru hizmet kurtarma yöntemlerinin geliştirilmesine katkı sağlayacaktır.

İşletme faaliyetlerinde; genel hizmet hataları, faturalama hataları, dikkatsiz, kaba, duyarsız veya bilgisiz çalışanlardan kaynaklı hizmet hataları gibi durumlarla karşılaşılması kaçınılmazdır (Aaker vd., 2004; Dutta ve Pullig, 2011; Keaveney, 1995). Hatalar; ürünlerle ilgili (fazla pişmiş yemek vb.) veya süreçlerle (sırada uzun süre bekleme vb.) ilgili olabilmektedir (Zhu vd., 2004). Alışverişlerde karşılaşılan hatalar, müşterilerin işletmelerce arzu edilmeyen davranışlarda (işletmeyi terk etme, olumsuz ağızdan ağza iletişim vb.) bulunmasına (Keaveney, 1995) ve işletme itibarının zarar görmesine neden olabilmektedir (De Blasio \& Veale, 2009). Dolayısıyla işletme ve çalışanların yaptığı hataları, müşterinin affetmesini sağlamada etkili olan faktörler incelenmesi gereken bir konudur.

\section{Affedicilik ve Müşteri Affediciliği}

Affedicilik; bireyin kendisine karşı haksız şekilde zarar verene yönelik; kin, olumsuz yargılama, sinirlenme, kaçınma ve kayıtsız davranış gibi duygu ve davranışlardan vazgeçip, merhamet, cömertlik ve ilişkileri devam ettirme gibi olumlu sonuçları artırma yönündeki istek olarak tanım- 
lanmaktadır (McCullough, 2000). Örgütsel bağlamda affedicilik, müşterinin örgütsel bir güven ihlali ve ilgili onarma çabalarına karşılık, misilleme, yabanclaşma ve işletme için diğer zararlı davranışlardan vazgeçerek cevap verme istekliliği olarak tanımlanabilmektedir (Finkel vd., 2002).

Kişisel özellikler olarak "uyumlu olma" (McCullugh, 2001) ve "unutma" (Lichtenfeld vd., 2015) ile yakından ilişkili olduğu görülen affedicilik, hata yapan tarafla ilişkilerin düzeltilmesi ve geliştirilmesi için önemli bir önceliktir. Kişiler arası affediciliğin, empati ve soruna yönelik atıflar gibi sosyo/bilişsel faktörler, özür dileme gibi hatayla ilgili faktörler, ilişki memnuniyeti, bağlllı̆̆ gibi ilişkisel faktörler ve uyumluluk gibi kişisel faktörlerden etkilendiğini araştırmalar göstermektedir (Finkel vd., 2002; Fincham vd., 2002). Dolayısıyla işletme ile müşteri arası ilişkilerde müşteri affediciliğinin bu faktörlerden etkilenmesi mümkündür.

Affedicilikle ilgili pazarlama literatüründe gerçekleştirilen çeşitli araştırmalar; hatanın büyüklüğünün (McCullough vd., 2003; Yelena ve Tojib, 2012), müşteri ile işletme arasındaki yakın ilişkilerin (Trampe, vd., 2014; Mittal vd., 2008; Hess vd., 2003), müşteri güveninin (Xie ve Peng, 2009), dindarlık gibi bireysel özelliklerin (Yelena ve Tojib, 2012), hizmet hatası büyüklügüünün (Zeeshan ve Khan, 2016), çalışan nezaketinin, hatanın bir kez olmasının, hizmetten genel olarak memnun olmanın, çalışanla çatışmaya girmeyip iç huzuru devam ettirme isteğinin, kendini çalışanın yerine koymanın, benzer hataların bazen olabileceğini düşünmenin, yanıttan memnun olmamaya rağmen sakin kalma isteğinin (Dana ve Luria, 2016), dayanışmacı kültürel anlayışın (Noth vd., 2015) ve özür dilemenin affediciliğe etkisi (Yelena ve Tojib, 2015) üzerinde yoğunlaşmaktadır. Ayrıca müşterinin affetmesini sağlamak ve olumlu müşteri davranışlarını desteklemek için izlenmesi gereken iletişim stratejileri (Lyon \& Cameron, 2004; Nguyen ve LeBlanc, 2001; Coombs ve Holladay, 2001), ve müşteri affediciliğinin müşteri tepkilerine (tekrar satın alma vb.) etkisi (Talaku, 2001; Noth vd., 2015) de araştırılmaktadır. Bu noktada özür dileme, işletmenin kontrolünde olan bir değişken olarak öncelikle araştırılan bir konudur. 


\section{Özür Dileme ve Affedicilik}

Bireyler arası ilişkilerde insanlar, samimi ve açık şekilde özür dileyenleri daha kolay affetmektedir (Struthers vd., 2008). İşletme için de özür dileme, hataların neden olduğu memnuniyetsizliği memnuniyete çevirmek için gösterilen örgütsel bir tepki olarak (Liao, 2007; Mattila vd., 2009), olumsuz durumun sorumluluğunun tam veya kısmi olarak kabul edilmesi anlamina gelmektedir (Roschk ve Kaiser, 2013). Müşteri affediciliğinde, özür dilemenin önemli bir rolü vardır. Çalışanların pişman olarak müşteriden özür dilemesi (Hill ve Boyd, 2015); genellikle satın almaların ve olumlu ağızdan ağıza iletişimin artması gibi olumlu sonuçlara neden olmaktadır (Basford vd., 2014; Liao, 2007; Lyon ve Cameron, 2004).

Bireyler arası bozulan ilişkilerin onarılmasında önemli bir araç olan özür dileme; pişmanlığın açıklanmasının yanında, oluşan zararın sorumluluğunun üstlenilmesi, zararın giderilmesi ve gelecekte olmasının engellenmesinin sağlanması gibi bileşenlerden meydana gelmektedir (Allan ve McKillop, 2010). Diğer taraftan özür dilemeyi hizmet kurtarma bakımından inceleyen çalışmalar, konuyu daha çok özür dilemenin varlığı ve yokluğu şeklinde ele almakta (Coulter, 2009), uygun olmayan özür dilemenin ilişkileri daha da kötüleştirebileceğine yönelik bulguları (Mitchell, 1989) yeterince göz önünde bulundurmamaktadır.

Özür dilemeyle ilgili gerçekleştirilen araştırmalar; gecikmeden (Wirtz ve Mattila, 2004; Holger ve Kaiser, 2013), isteyerek (McLennan vd., 2014) karşı tarafın ihtiyaçlarına önem vererek (diğerleri odaklı; pişmanlığı açıklama, zararı çözmek için öneriler geliştirme, çaba gösterme vb.) (Allan vd., 2015), empatik şekilde (Holger ve Kaiser, 2013), karşı tarafın endişelerini açıklamasına imkan vererek (Min vd., 2012), sorunu dışsal faktörlere dayandırmayarak (Yuan vd., 2016) ve müşteride oluşan zararı tazmin ederek (Joireman vd., 2013) özür dilemenin önemine dikkat çekmektedir. Kısaca bir sorunun samimiyetle kabul edilmesi, müşterinin olumlu tutumlarını devam ettirmesine, sorunu önemsizleştirmesine (Lindssey-Mullikin, 2003) ve özellikle müşteri zararı tazmin edildiğinde müşterinin güdülerinin olumluya dönüşmesine ve işletme ile anlaşma isteği oluşmasına neden olmaktadır (Joireman vd., 2013). Türkiye'deki pazarlama literatüründe hizmet sektöründe karşılaşılan hizmet kurtarma stratejileri dikkat 
çekilmekte, perakende satış sektöründe karşılaşılan sorunlar neticesinde özür dilemenin rolü hakkında araştırma yapılmadığı görülmektedir.

\section{Yapıcı Özür Dilemenin Müşteri Affediciliğindeki Rolü: Kırıkkale İlinde Market Alışverişlerine Yönelik Bir Araştırma}

\section{Araştırma Amacı ve Yöntemi}

$\mathrm{Bu}$ araştırmanın amac1, firma hataları neticesinde müşteriden özür dilemenin müşteri affediciliği üzerindeki etkisini araştırmaktır. Araştırma birincil elden veri toplama yöntemlerinden yüz yüze anket kullanılarak gerçekleştirilmiştir. Kırıkkale ilinde kolayda örnekleme yöntemi ile 380 kişiye anket uygulanmış, elde edilen veriler bilgisayar destekli istatistik programında analiz edilmiş ve sonuçlar yorumlanmıştır.

Soru formunda öncelikle katılımcılara market alışverişlerinde karşılaştığ ve işletmeye ilettiği en önemli işletme hatasını belirtmeleri istenmiştir. Ardından bu hatayla ilgili işletmenin özür dileme çabalarının algılanmasıyla ilgili beşli Likert formatında ifadeler yöneltilmiştir. Bu ifadelerin oluşturulmasında Xie ve Peng'in (2009) çalışmasından yararlanılmıştır (Xie ve Peng, 2009). Son olarak müşteri affediciliğini tespit etmek üzere oluşturulan ifadelerde Yelena ve Tojib (2012) ve Xie ve Peng'in (2009) çalışmalarından yararlanılmıştır. Son olarak katılımcıların yaş, cinsiyet, aylık gelir, eğitim ve mesleklerine ilişkin sorular yöneltilmiştir.

\section{Araştırma Bulguları}

Araştırmaya 380 kişi katılmıştır. Katılımcıların \% 51,6'sı (196 kişi) erkek, \% 48,4'ü (184 kişi) kadındır. Gelir bakımından katılımcıların \% 37,9'u (144 kişi) 2000 TL ve altı gelire, \% 47,6'sı (181 kişi) 2001-3000 TL gelir aralıl1ğındadır. Eğitim düzeyi bakımından katılımcıların \% 40,8'i (155 kişi) lisans düzeyinde, \% 20'si (76 kişi) lise düzeyinde eğitime sahiptir. Yaş bakımından ise katılımcıların \% 68,1'inin (259 kişi) 30 ve altı yaş aralığında olduğu tespit edilmiştir.

Araştırmaya katılanların market alışverişlerinde karşılaştı̆̆ hatalar sırasıyla; ürünle ilgili (bozuk ürün, ambalajı açık ürün, kalitesiz ürün, erken 
bozulma, son kullanma tarihinin yakın olması vb.), süreç/hizmet veya çalişanlarla ilgili hatalar (kuyruk sorunu, acelecilik, temizlik ve hijyen, satış elamanı davranışları vb.) ve fiyatla/ödeme koşullarından (yüksek fiyat, kredi kartı ile ödeyememe vb.) oluşmaktadır.

Araştırma değişkenlerinin yapısal geçerliliğini test etmek üzere faktör analizi gerçekleştirilmiştir. Yapıcı özür dileme değişkenine yönelik ifadeler için gerçekleştirilen faktör analizi sonucunda; KMO uygunluk katsayısı 0,897 ve Bartlett değeri anlamlı olarak tespit edilmiştir. Yapıcı özür dilemeyle ilgili oluşturulan ifadeler toplam varyansın \% 64,015'ini açıklayan tek faktör altında toplanmıştır. Buna göre yapıcı özür dileme; müşteriye çözüm için yapılanları anlatma, sorunu dürüst şekilde ele alma, olumsuz duyguları giderme, sorunla ilgili bilgilendirilme ve zararı somut şekilde telafi etme gibi maddelerden meydana gelmektedir.

Tablo 1. Yapıcı Özür Dileme

\begin{tabular}{lllll}
\hline & $\begin{array}{l}\text { Faktör } \\
\text { Yükü }\end{array}$ & $\begin{array}{l}\text { Öz } \\
\text { değer }\end{array}$ & $\begin{array}{l}\text { Açılanan } \\
\text { Varyans }\end{array}$ & $\begin{array}{l}\text { Toplam } \\
\text { Varyans }\end{array}$ \\
\hline $\begin{array}{l}\text { İşletme sorunun çözümü } \\
\text { için yaptıklarını anlatmıştır }\end{array}$ &, 857 & 5,761 & 64,015 & 64,015 \\
\hline $\begin{array}{l}\text { İşetme sorunu dürüst şekilde } \\
\text { ele almıştır }\end{array}$ &, 843 & & \\
\hline $\begin{array}{l}\text { İşletme karşılık beklemeden } \\
\text { sorunu düzeltmeye çalıştı }\end{array}$ &, 830 & & \\
\hline Olumsuz duygularım giderilmiştir &, 818 & & \\
\hline $\begin{array}{l}\text { İşletme müş̧teri sorunlarını } \\
\text { çözerken tutarlıdır }\end{array}$ &, 796 & & \\
\hline $\begin{array}{l}\text { Olumsuzluğun nedeni } \\
\text { hakkında bilgilendirildim }\end{array}$ &, 794 & & \\
\hline $\begin{array}{l}\text { Zararım ekonomik } \\
\text { olarak karşılanmıştır }\end{array}$ &, 794 & & \\
\hline $\begin{array}{l}\text { Zararım somut şekilde } \\
\text { telafi edilmiştir }\end{array}$ &, 776 & & \\
\hline Açıkça özür dilenmiştir &, 680 & & \\
\hline KMO & & & \\
\hline Sig. & & & \\
\hline
\end{tabular}

İkinci olarak, müşteri affediciliği ile ilgili ifadeler faktör analizine tabi tutulmuş ve KMO katsayısı 0,668 ve Bartlett değeri anlamlı olarak tespit edilmiş ve ifadeler toplam varyansın \% 65,729'unu açıklayan tek faktör 
altında toplamıştır. Bu değişken müşterinin işletmeyi affetmesi, işletmeyle ilgili düşüncelerinin düzelmesi ve işletmeyle iletişimlerini devam ettirmesi ile ilgili maddelerden oluşmaktadır.

Tablo 2. Müşteri Affediciliği

\begin{tabular}{lllll}
\hline & $\begin{array}{l}\text { Faktör } \\
\text { Yükü }\end{array}$ & Öz değer & $\begin{array}{l}\text { Açıklanan } \\
\text { Varyans }\end{array}$ & $\begin{array}{l}\text { Toplam } \\
\text { Varyans }\end{array}$ \\
\hline & & 1,972 & 65,729 & 65,729 \\
\hline $\begin{array}{l}\text { İşletmeyle iletişimlerimi } \\
\text { vam ettiririm }\end{array}$ & de- &, 848 & & \\
\hline $\begin{array}{l}\text { İşletmeyle ilgili } \\
\text { düşüncelerim düzelir }\end{array}$ &, 822 & & \\
\hline $\begin{array}{l}\text { İşletmeyi affederim } \\
\text { KMO }\end{array}$ &, 759 & &, 668 \\
\hline Sig. & & &, 000 \\
\hline
\end{tabular}

Araştırma kapsamında yapıcı özür dileme ile müşteri affediciliği arasındaki birlikte değişimi test etmek üzere gerçekleştirilen korelasyon analizine göre, değişkenler arasında orta düzeyde ilişki tespit edilmiştir. Buna göre, işletmelerin yaptığı hatalarda yapıcı özür dilemenin müşteri affediciliğinde önemli rolü olabileceği görülmektedir.

Tablo 3. Korelasyon Analizi

\begin{tabular}{ll}
\hline & Müşteri Affediciliği \\
\hline Yapıcı Özür Dileme & $\frac{, 427^{* *}}{\text { Sig. ,000 }}$ \\
\hline
\end{tabular}

Pearson Korelasyonu (r)

Yapıcı özür dilemenin müşteri affediciliği üzerindeki etkisini test etmek üzere gerçekleştirilen regresyon analizine göre modelin anlamlı olduğu görülmüştür. Buna göre yapıcı özür dileme affediciliğin \% 18'ini açıklamaktadır. Açıklama oranın düşük olmasının, literatürde incelendiği üzere bireysel, durumsal, kültürel ve çevresel pek çok faktörün müşteri affediciliğinde önemli rolü olmasından kaynakladığ 1 düşünülmektedir. Buna karşın, işletme kontrolünde olan bir değişken olarak yapıcı özür dilemenin müşterinin hatalar karşısında işletmeyi affetmesini sağlamada göz ardı edilemeyecek bir değişken olduğu anlaşılmaktadır. 
Tablo 4. Regresyon Analizi

\begin{tabular}{llll}
\hline Bağımlı Değişken: Müşteri Affediciliği & & & \\
\hline & Beta & t & sig. \\
\hline Yapıcı Özür Dileme & 0,409 & 7,242 & 0,000 \\
\hline F & 52,450 & Sig. 0,000 & \\
\hline$R$ & 0,427 & & \\
\hline$R^{2}$ & 0,182 & & \\
\hline
\end{tabular}

Son olarak hata türüne göre araştırma değişkenleri arasındaki ilişkilerin farklılaşma durumu incelenmiştir. Buna göre yapıcı özür dilemenin müşteri affediciliğiyle ilişkisinin en fazla fiyat/ödeme koşulları sorunu durumunda gerçekleştiği görülmektedir. Ayrıca bu sorun durumunda, yapıcı özür dilemenin affediciliği açılama oranı da \% 54'tür. Diğer taraftan ürün sorunları ve süreç/hizmet/çalışan sorunlarında yapıc1 özür dilemeyle müşteri affediciliği arasındaki ilişkiler daha düşüktür. Kısaca yapıcı özür dilemenin fiyat ve ödeme koşulları durumunda diğer sorunlara göre çok daha etkili olduğu anlaşılmaktadır.

Tablo 5. Hata Türlerine Göre Yapıcı Özür Dileme ile Müşteri Affediciliği İlişkisi

\begin{tabular}{ll}
\hline Ürün Hataları & Müşteri Affediciliği \\
\hline Yapıcı Özür Dileme & $\frac{0,326}{\text { Sig. 0,000 }}$ \\
\hline Süreç/Hizmet/Çalışan Hataları & \\
\hline Yapıcı Özür Dileme & 0,419 \\
\hline Fiyat/Ödeme Koşulları Sorunları & Sig. 0,000 \\
\hline Yapıcı Özür Dileme & 0,742 \\
\hline Pearson Korelasyonu (r) & Sig. 0,000 \\
\hline
\end{tabular}

\section{Sonuç}

İşletmelerin yaptığı hatalar neticesinde müşterilerin karşılaştığı olumsuz durumları yönetmesi gerekmektedir. Bu doğrultuda müşteriye özür dilemenin önemli bir faktör olduğu fikri, pazarlama literatüründeki 
araştırmalarda tespit edilmekte ve bu araştırmada bir saha çalışması ile desteklenmektedir. Ancak yapıcı özür dilemenin, müşteri affediciliğini açıklama oranının düşük olması, müşterinin işletmeyi affetmesini sağlamada tek başına yeterli bir faktör olmadığını göstermektedir.

Ayrıca yapıcı özür dilemenin en fazla fiyat/ödeme koşullarıyla ilgili hatalarda etkili olduğu araştırmada tespit edilmiştir. Dolayısıyla müşterinin kredi kartı ile ödeme yapamama, küsuratlı fiyat uygulaması ve yüksek fiyat gibi müşterinin hata olarak algıladığı durumlar karşısında dilediği özrün diğer hatalara göre daha etkili olduğu anlaşılmaktadır. Bu sorunla ilgili müşteriye açıkça özür dilenmesi ve sorunun nedeni ve yapılanlar hakkında bilgi verilmesi ve karşlık beklemeden sorunun düzeltilmeye çalışıldığı algısının oluşturulması, müşterinin işletmeyi affetmesinde önemli bir faktördür.

Bozuk ürün, açık ambalajlı ürün, son kullanma tarihi çok yaklaşan ürün, kalitesiz ürün, kasada kuyruk bekleme, temizlik/hijyen ve satış elemanı davranışlarıyla ilgili sorunlarda müşteri affediciliği üzerinde yapıcı özür dilemenin pozitif etkisi anlamlı olmasına karşın daha düşüktür. Bu durumlarda, yapıcı özür dilemenin etkinliği azalmaktadır. Çalışanların dikkatsizlik, ihmal veya bilinçli davranışlarının neden olduğu veya kasada kuyruk bekleme sorununda olduğu gibi çalışanların yetkileriyle çözüm üretemediği durumlarda, yapıcı özür dilemenin müşteri affediciliğindeki önemli rolünün azaldığı anlaşılmaktadır. İşletmelerin bu gibi, müşteriler tarafından hata olarak algılanan sorunların farkında olması ve müşteri affediciliğini kazanmak için üst yönetim veya işletme düzeyinde çözümler üretmesinin mümkün olduğu düşünülmektedir. 


\title{
EXTENDED ABSTRACT
}

\section{The Role of Constructive Apology in Customer Forgiveness: A Research on Market Shopping in Kirıkkale Province}

\author{
Ertuğrul Karakaya - İbrahim Bozacı \\ Kırıkkale University
}

Marketing researchers suggest that forgiveness can have significant effects on consumer behavior (Xie and Peng, 2009; Beverland et al., 2009; Beverlan et al., 2010; Tsarenko and Tojib, 2012). However, customer forgiveness is not an adequately studied issue in enterprises (Tsarenko and Tojib, 2011). On the other hand, customer response to service faults is mostly examined in terms of customer retaliation, complaint and firm changing behaviors (Grégoire et al., 2009). In order to avoid any damage and correction of relations with the customer, it is a matter that needs to be examined in order to forgive the mistakes made by the company or its employees. Understanding the variables that affect customer forgiveness will contribute to not losing customers and developing correct service recovery methods.

Apology, which is an important tool in the restoration of distorted relationships between individuals; is composed of components such as taking responsibility for the damage, eliminating the damage and preventing it from happening in the future (Allan \& McKillop, 2010). On the other hand, studies examining apology in terms of service recovery address the issue as the presence and absence of apology (Coulter, 2009), and do not take into consideration the findings that inappropriate apology can make relations worse (Mitchell, 1989).

Studies take attention to the importance of an apology that is made without delay (Wirtz and Mattila, 2004; Holger and Kaiser, 2013), willingly (McLennan et al., 2014), pays attention to the needs of the other party (others focused; explaining regret, developing suggestions to resolve the harm, making efforts, etc.) (Allan et al. , 2015), empathically (Holger and Kaiser, 2013), allows the other party to explain their concerns (Min et al., 
2012), and compensation for the damage to the customer (Joireman et al., 2012). 2013). In short, accepting a problem with sincerity causes the customer to continue his positive attitudes, to trivialize the problem (LindsseyMullikin, 2003), and especially when the customer is compensated for the damage, the customer's motives turn into positive and a desire for agreement with the enterprise occurs (Joireman et al., 2013).

The aim of this research is to investigate the effect of customer apology on customer forgiveness as a result of company failures. The research was conducted by using face - to - face questionnaire which is one of the primary data collection methods. In the province of Kırıkkale, 380 people were surveyed by convenience sampling method and the data were analyzed in computer aided statistical program and the results were interpreted.

In the survey form, the participants were first asked to indicate the most important operational error they faced during the grocery shopping. Then, five-point Likert format expressions were directed to measure the perception apology. Xie and Peng's (2009) In the statements created to determine customer forgiveness, the studies of Yelena and Tojib (2012) and Xie and Peng (2009) were used. Finally, questions about age, gender, monthly income, education and occupation of the participants were asked.

380 people participated in the study. Of the participants, 51.6\% (196 people) were male and $48.4 \%$ (184 people) were female. In terms of income, 37.9\% (144 people) of the participants were $2000 \mathrm{TL}$ and below, $47.6 \%$ (181 people) were in the income range of 2001-3000 TL. In terms of education level, $40.8 \%$ (155 people) of the participants had undergraduate education and $20 \%$ (76 people) had high school education. In terms of age, it was found that $68.1 \%$ of the participants ( 259 people) were between the ages of 30 and under.

According to the regression analysis conducted to test the effect of constructive apology on customer forgiveness, the model was found to be significant. Consequently, constructive apology explains $18 \%$ of forgiveness. The low rate of explanation is thought to be due to the fact that many individual, situational, cultural and environmental factors have an important role in customer forgiveness as discussed in the literature. On the other hand, constructive apology as a variable that is in the control of the 
enterprise is understood to be a variable that cannot be ignored in ensuring that the customer forgives the enterprise in case of mistakes.

Businesses should manage the negative situations faced by customers as a result of failures made. In this direction, the idea that apologizing to the customer, who faced with negative situations, is an important factor as determined in the researches in the marketing literature and supported by a field study in this research. However, the fact that constructive apology is low in explaining customer forgiveness shows that the apology alone is not a sufficient factor in forgiving the enterprise.

\section{Kaynakça / References}

Aaker, J., Fournier, S., ve Brasel, S. A. (2004). When good brands do bad. Journal of Consumer Research, 31(1), 1-16.

Allan, A., ve McKillop, D. (2010). The health implications of apologizing after an adverse event. International Journal for Quality in Health Care, 22(2), 126-131.

Allan, A., McKillop, D., Dooley, J., Allan, M. M., ve Preece, D. A. (2015). Apologies following an adverse medical event: The importance of focusing on the consumer's needs. Patient education and counseling, 98(9), 1058-1062.

Basford, T. E., Offermann, L. R.,ve Behrend, T. S. (2014). Please accept my sincerest apologies: Examining follower reactions to leader apology. Journal of Business Ethics, 119(1), 99-117.

Beverland, M. B., Chung, E., ve Kates, S. M. (2009). Exploring consumers' conflict styles: Grudges and forgiveness following marketer failure. Advances in Consumer Research, 36, 438-443.

Beverland, M. B., Kates, S. M., Lindgreen, A., ve Chung, E. (2010). Exploring consumer conflict management in service encounters. Journal of the Academy of Marketing Science, 38(5), 617-633.

Coombs, W. T., ve Holladay, S. J. (2001). An extended examination of the crisis situations: A fusion of the relational management and symbolic approaches. Journal of Public Relations Research, 13(4), 321-340.

Coulter, K. S. (2009). Enough is enough! Or is it? Factors that impact switching intentions in extended travel service transactions. Journal of Travel and Tourism Marketing, 26(2), 144-155. 
Dana, Y. ve Luria, G. (2016). Customer forgiveness of unsatisfactory service: manifestations and antecedents. Service Business, 10(3), 557-579.

De Blasio, A. ve Veale, R. (2009). Why say sorry? Influencing consumer perceptions post organizational crises. Australasian Marketing Journal, $7(2), 75-83$.

Dutta, S., ve Pullig, C. (2011). Effectiveness of corporate responses to brand crises: The role of crisis type and response strategies. Journal of Business Research, 64(12), 1281-1287.

Fincham, F. D., Paleari, F. G., ve Regalia, C. (2002). Forgiveness in marriage: The role of relationship quality, attributions, and empathy. Personal Relationships, 9(1), 27-37.

Finkel, E. J., Rusbult, C. E., Kumashiro, M., ve Hannon, P. A. (2002). Dealing with betrayal in close relationships: Does commitment promote forgiveness? Journal of Personality and Social Psychology, 82, 956-974.

Gre' goire, Y., Tripp, T.M. ve Legoux, R. (2009). When customer love turns into lasting hate: the effects of relationship strength and time on customer revenge and avoidance. Journal of Marketing, 73(6), 18-32.

Hess, R.L., Ganesan, S. ve Klein, N.M. (2003). Service failure and recovery: the impact of relationship factors on customer satisfaction. Journal of the Academy of the Marketing Science, 31, 127-145

Hill, K. M., ve Boyd, D.P. (2015). Who should apologize when an employee transgresses? Source effects on apology effectiveness. Journal of Business Ethics, 130(1), 163-170.

Joireman, J., Grégoire, Y., Devezer, B., ve Tripp, T. M. (2013). When do customers offer firms a "second chance" following a double deviation? The impact of inferred firm motives on customer revenge and reconciliation. Journal of Retailing, 89(3), 315- 337.

Keaveney, S.M. (1995). Customer switching behavior in service industries: an exploratory study. Journal of Marketing, 59(2), 71-82.

Liao, H. (2007). Do it right this time: The role of employee service recovery performance in customerperceived justice and customer loyalty after service failures. Journal of Applied Psychology, 92(2), 475-489.

Lichtenfeld, S., Buechner, V. L., Maier, M. A., ve Fernández-Capo, M. (2015). Forgive and forget: Differences between decisional and emotional forgiveness. PloS one, 10(5), e0125561. 
Lyon, L., ve Cameron, G. T. (2004). A relational approach examining the interplay of prior reputation and immediate response to a crisis. Journal of Public Relations Research, 16(3), 213-241.

Mattila, A. S., Cho, W., ve Ro, H. (2009). The joint effects of service failure mode, recovery effort, and gender on customers' post recovery satisfaction. Journal of Travel and Tourism Marketing, 26(2), 120-128.

McCullough, M. E., Fincham, F. D., ve Tsang, J.-A. (2003). Forgiveness, forbearance, and time: The temporal unfolding of transgression-related interpersonal motivations. Journal of Personality and Social Psychology, 84(3), 540-557.

McCullough, M.E. (2000). Forgiveness as human strength: theory, measurement, and links to well-being. Journal of Social and Clinical Psychology, 19(1), 43-55.

McCullough, M.E. (2001). Forgiveness who does it and how do they do it. Current Directions in Psychological Science, 10(6), 194-197.

McLennan, S, Walker, S. ve Rich, L.E. (2014). Should health care providers be forced to apologise after things go wrong?. Journal of bioethical inquiry, 11(4), 431-435.

Min, K., S., Jung, M. J. ve Ryu, K. (2012). I apologize. I understand your concerns: When an empathetic apology works. Advances in Consumer Research, 40, 939-940.

Mitchell, C. E. (1989). Effects of apology on marital and family relationships. Family Therapy: The Journal of the California Graduate School of Family Psychology, 16(3), 283-287.

Mittal, V., Huppertz, J.W. ve Khare, A. (2008). Customer complaining: the role of tie strength and information control. Journal of Retailing, 84(2), 195-204.

Nguyen, N., ve LeBlanc, G. (2001). Image and reputation of higher education institutions in students' retention decisions. International Journal of Educational Management, 15(6), 303-311.

Noth, A.C., Jaroenwanit, P., ve Brown, R. (2015). The Roles of Forgiveness towards Repurchase Intentions from a Cross Cultural Perspective. Athens Journal of Business \& Economics, 1(3), 221-234.

Roschk, H., ve Kaiser, S. (2013). The nature of an apology: An experimental study on how to apologize after a service failure. Marketing Letters, 24(3), 293-309. 
Struthers, C. W., Eaton, J., Santelli, A. G., Uchiyama, M., ve Shirvani, N. (2008). The effects of attributions of intent and apology on forgiveness: When saying sorry may not help the story. Journal of Experimental Social Psychology, 44(4), 983-992.

Takaku, S. (2001). The effects of apology and perspective taking on interpersonal forgiveness: a dissonance-attribution model of interpersonal forgiveness. The Journal of Social Psychology, 141, 494-508.

Trampe, D., Konuş, U. ve Verhoef, P.C., (2014). Customer responses to channel migration strategies toward the e-channel. Journal of Interactive Marketing, 28, 257-270.

Tsarenko, Y., ve Tojib, D. (2011). A Transactional Model of Forgiveness in Service Failure Context: A Customer-Driven Approach. Journal of Services Marketing, 25(5), 381-392.

Tsarenko, Y., ve Tojib, D. (2012). The role of personality characteristics and service failure severity in consumer forgiveness and service outcomes. Journal of Marketing Management, 28(9-10), 1217-1239.

Wirtz, J., ve Mattila, A. S. (2004). Consumer responses to compensation, speed of recovery and apology after a service Failure. International Journal of Service Industry Management, 15, 150-66.

Xie, Y., ve Peng, S. (2009). How to repair customer trust after negative publicity: The roles of competence, integrity, benevolence, and forgiveness. Psychology \& Marketing, 26(7), 572-589.

Yelena, T. ve Tojib, D. (2012). The role of personality characteristics and service failure severity in consumer forgiveness and service outcomes. Journal of Marketing Management, 28(9-10), 1217-1239.

Yelena, T. ve Tojib, D. (2015). Consumers' forgiveness after brand transgression: the effect of the firm's corporate social responsibility and response. Journal of Marketing Management, 31(17-18), 1851-1877.

Yuan, D., Yuan, D., Cui, G., Cui, G., Lai, L., ve Lai, L. (2016). Sorry seems to be the hardest word: consumer reactions to self-attributions by firms apologizing for a brand crisis. Journal of Consumer Marketing, 33(4), 281-291.

Zeeshan, R. ve Khan, M.I. (2016). Impact of service failure severity and agreeableness on consumer switchover intention: Mediating role of consumer forgiveness. Asia Pacific Journal of Marketing and Logistics, 28(3), 420-434. 
Yapıcı Özür Dilemenin Müşteri Affediciliğindeki Rolü: Kırıkkale İlinde Market Alışverişlerine Yönelik Bir Araştırma

Zhu, Z., Sivakumar, K., ve Parasuraman, A. (2004). A mathematical model of service failure and recovery strategies. Decision Sciences, 35(3), 493525 .

Kaynakça Bilgisi / Citation Information

Karakaya, E. ve Bozacı, İ. (2019). Yapıcı özür dilemenin müşteri affediciliğindeki rolü: Kırıkkale İlinde market alışverişlerine yönelik bir araştırma OPUS-Uluslararası Toplum Araştırmaları Dergisi, 13(19), 1331-1347. DOI: 10.26466/opus.568542 